\title{
Effects of different strategies for feeding supplements on milk production responses in cows grazing a restricted pasture allowance
}

\author{
M. J. Auldist, ${ }^{1}$ L. C. Marett, J. S. Greenwood, M. Hannah, J. L. Jacobs, and W. J. Wales \\ Future Farming Systems Research Division, Department of Primary Industries, Ellinbank, VIC 3821, Australia
}

\begin{abstract}
Milk production responses of grazing cows offered supplements in different ways were measured. HolsteinFriesian cows, averaging $227 \mathrm{~d}$ in milk, were allocated into 6 groups of 36 , with 2 groups randomly assigned to each of 3 feeding strategies: (1) cows grazed perennial ryegrass pasture supplemented with milled barley grain fed in the milking parlor and pasture silage offered in the paddock (control); (2) same pasture and allotment supplemented with the same amounts of milled barley grain and pasture silage, but presented as a mixed ration after each milking (PMR 1); and (3) same pasture and allotment, supplemented with a mixed ration of milled barley grain, alfalfa hay, corn silage, and crushed corn grain (PMR 2). For all strategies, supplements provided the same metabolizable energy and grain:forage ratio. [75:25, dry matter (DM) basis]. Each group of 36 cows was further allocated into 4 groups of 9 , which were assigned to receive $6,8,10$, or $12 \mathrm{~kg}$ of supplement DM/cow per day. Thus, there were 2 replicated groups per supplement amount per dietary strategy. The experiment had a 14-d adaptation period and an 11-d measurement period. Pasture allotment was approximately $14 \mathrm{~kg}$ of $\mathrm{DM} / \mathrm{d}$ for all cows and was offered in addition to the supplement. Positive quadratic responses to increasing amounts of supplement were observed for yield of milk, energy-corrected milk (ECM), and fat and protein, and positive linear responses for concentrations of fat and protein for cows on all 3 supplement feeding strategies. No difference existed between feeding strategy groups in yield of milk, ECM, or protein at any amount of supplement offered, but yield and concentration of fat was higher in PMR 2 cows compared with control and PMR 1 cows at the highest amounts of supplementation. Responses in marginal ECM production per additional kilogram of supplement were also greater for PMR 2 than control and PMR 1 cows when large amounts of supplement were consumed. For all diets, marked daily
\end{abstract}

Received August 24, 2012.

Accepted October 19, 2012.

${ }^{1}$ Corresponding author: Martin.Auldist@dpi.vic.gov.au variation occurred in ruminal fluid volatile fatty acids and $\mathrm{pH}$, especially in cows fed the largest amounts of supplement. It was concluded that when supplements are fed to grazing dairy cows, a simple mix of grain and pasture silage has no benefit over traditional strategies of feeding grain in the parlor and forage in the paddock. However, yield of milk fat and marginal milk production responses can be greater if the strategy uses an isoenergetic ration that also contains alfalfa hay, corn silage, and corn grain.

Key words: partial mixed ration, pasture, milk response, supplement

\section{INTRODUCTION}

In many parts of the world, pasture is a significant source of nutrients for lactating dairy cattle. It is likely the numbers of dairy cattle maintained in full or partial grazing systems, or simply fed more forage, will increase in the future, given the increasing global demand for grain as sources of human food, animal feed, and fuel. Pasture, however, does not provide an optimal mix of nutrients for sustaining the high-producing dairy cow (Kolver and Muller, 1998). As a consequence, most grazing systems also incorporate supplementary feeds in the form of forage and grain or pelleted concentrates (Bargo et al., 2003; Wales et al., 2006). Reduced pasture availability due to low rainfall, in combination with management decisions to increase stocking rates or per-cow production, can further increase reliance on supplementary feeds to meet the nutritional needs of the milking herd (Armstrong et al., 2010). Choosing and implementing the most efficient and appropriate systems for providing such supplements from the wide variety available can be a challenge for dairy producers.

In southeast Australia, as well as other parts of the world, pasture is typically supplemented with grain or pelleted concentrates fed in the milking parlor. Production increases in response to supplements fed in this way can be good (Walker et al., 2001; Leddin et al., 2009), but responses are curvilinear, with poorer responses being observed as the amount of grain increases (Stockdale et al., 1987; Walker et al., 2001; Kellaway and Harrington, 2004). Noticeable reductions in milk 
production responses have been reported when pasture is supplemented with more than 5 to $9 \mathrm{~kg}$ of grain DM/ cow per day, depending on stage of lactation and pasture quality (Walker et al., 2001; Beever and Doyle, 2007). It is well established that cows can consume much more grain than this and produce large quantities of milk with no untoward health effects, so such diminishing responses to supplements may be due in part to inefficiencies in rumen fermentation when large amounts of grain are ingested quickly (Dixon and Stockdale, 1999; Wales et al., 2000). Feeding large amounts of cereal supplements in the parlor can increase variations in rumen fluid $\mathrm{pH}$ and the time each day that $\mathrm{pH}$ is below 6.0 (Wales and Doyle, 2003), which can, in turn, impair NDF digestion (Mould et al., 1983; Leddin et al., 2010) and thus reduce milk production responses (Doyle et al., 2005). Feeding grain can also lead to substitution effects, whereby less herbage is consumed, thus further reducing the observed milk production response to increased supplementation (Dixon and Stockdale, 1999).

An alternative method of feeding large amounts of supplements to grazing dairy cows is to feed them as a partial mixed ration (PMR), which is defined as a TMR fed to cattle on a feed pad between bouts of grazing (Bargo et al., 2002). A well-formulated PMR that is consumed over a longer period of time during the day than when grain is fed in the parlor could lead to a more stable ruminal fermentation with less variation and lower declines in rumen fluid $\mathrm{pH}$. For this reason, it has been suggested that providing supplements to grazing cows as a PMR may lead to improved milk production responses compared with feeding concentrates in the parlor (Beever and Doyle, 2007). However, we do not have a full definition of the range of potentially useful supplementation strategies.

The objective of this experiment was, therefore, to evaluate the efficiency of different strategies for feeding supplementary forage and grain to grazing cows. Specifically, strategies that incorporated 2 differently formulated PMR were compared with the traditional strategy of feeding grain in the parlor and forage in the paddock. The hypotheses tested were as follows: (1) increasing the amounts of grain fed in the milking parlor and forage supplement fed in the paddock to cows in late-lactation grazing a low allowance of fall pasture would lead to a quadratic increase in production of ECM; (2) feeding the same amounts of the same concentrate and forage supplements, but as a simple PMR, to cows in late-lactation grazing a low allowance of fall pasture would lead to a linear increase in ECM production, and the marginal ECM production response would be greater than if the supplements were fed separately in the parlor and paddock; and (3) increasing the amounts of a PMR formulated to be isoen- ergetic, but containing a slowly digestible starch source, would also lead to a linear increase in ECM production, and marginal ECM production response to additional supplement would be greater than for the simple PMR. Inherent in these hypotheses is that part of any negative or diminishing returns would be an altered pattern of rumen fermentation and $\mathrm{pH}$.

\section{MATERIALS AND METHODS}

\section{Cows and Design}

The experiment was conducted in late fall at the Department of Primary Industries (DPI), Ellinbank Centre, Victoria, Australia (latitude $38^{\circ} 14^{\prime}$ S, longitude $\left.145^{\circ} 56^{\prime} \mathrm{E}\right)$. All procedures were conducted in accordance with the Australian Code of Practice for the Care and Use of Animals for Scientific Purposes (National Health and Medical Research Council, 2004). Approval to proceed was obtained from the DPI Agricultural Research and Extension Animal Ethics Committee.

The experiment used 216 multiparous seasonally calving Holstein-Friesian dairy cows (Table 1), including 24 rumen-fistulated cows. All cows were between 3 and $7 \mathrm{yr}$ old (in their second to fifth lactation) and were milked twice daily at ca. 0700 and $1500 \mathrm{~h}$. Cows had calved in late winter/early spring and were an average of 227 DIM (range 177 to 256 DIM). All cows were weighed immediately before the experiment.

The experiment was conducted over $25 \mathrm{~d}$. This included a 14-d preexperimental period during which cows adapted to the amount of supplement. After the preexperimental period, there was an 11-d measurement period during which DMI and milk production were measured.

\section{Supplement Feeding Strategies}

As soon as all cows had calved, they were allocated into 6 groups of 36 cows balanced for DIM, age, BW, and production of milk, milk protein, and milk fat in the previous lactation according to the method of Baird (1994; Table 2). Each group included 4 rumen-fistulated cows. One of 3 feeding systems was then randomly assigned to 2 of the 6 groups. The feeding systems were as follows:

(1) Control: cows grazed perennial ryegrass (Lolium perenne L.) pasture supplemented with milled barley grain fed twice daily in the milking parlor and pasture silage provided in the paddock. The ratio of grain:forage fed as supplement was 0.75:0.25 (DM basis). The pasture allowance was approximately $14 \mathrm{~kg} \mathrm{DM} /$ cow per day; 


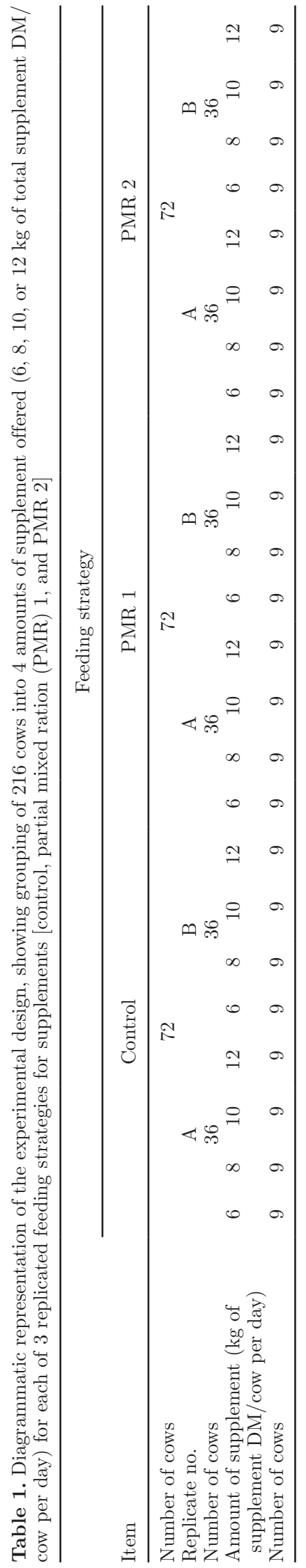

(2) PMR 1: cows grazed perennial ryegrass pasture twice daily at the same allowance as the control cows. They were also offered the same amounts of milled barley grain and pasture silage, but these supplements were mixed and chopped in a feed wagon (model K160; Richard Keenan and Co. Ltd., Co. Carlow, Ireland) before being presented on a concrete feed pad immediately after each milking (half the daily ration was fed following each milking). Water was added to the ration such that the final DM content of the ration approximated $50 \%$;

(3) PMR 2: cows grazed perennial ryegrass pasture twice daily at the same allowance as the control cows. They were also offered a PMR comprising milled barley grain (25\% of total supplement $\mathrm{DM})$, crushed corn grain $(30 \%$ of DM), corn silage (20\% of DM), and alfalfa hay (25\% of DM), again fed after each milking. Water was added to the ration such that the final DM content of the ration approximated $50 \%$. The ration in this treatment provided the same estimated ME intake as the supplements offered to the control and PMR 1 cows, and had the same ratio of grain:forage (75:25 DM basis, including the grain component of the corn silage), but was formulated to ferment more slowly.

Establishment of cow requirements and adequacy of diets was based on the CPM Dairy nutrition model (Tedeschi et al., 2008). Nutritive characteristics of the ration components are presented in Table 3. As part of their ration, all cows received a vitamin and mineral pellet (Nutrifeed Hi-Milker; Debenham Australia Pty Ltd., Leongatha, Victoria, Australia) that contained tylosin $(110 \mathrm{mg} / 100 \mathrm{~g}$ of pellets). Cows at the highest rate of supplementation (12 kg of $\mathrm{DM} /$ cow per day) received this supplement at the rate recommended by the manufacturers (125 g of pellets/cow per day), whereas cows receiving lower amounts of supplement received proportionally less (i.e., cows offered $6 \mathrm{~kg}$ of DM supplement/d received $62.5 \mathrm{~g} /$ cow per day of the vitamin and mineral pellet). Control cows received their vitamin and mineral pellets mixed with their grain at milking time, whereas cows offered PMR 1 and PMR 2 received theirs mixed into their PMR.

\section{Amounts of Supplement}

Cows received approximately $10 \mathrm{~kg}$ of $\mathrm{DM} /$ cow per day of their allocated ration from soon after all cows had calved until the current experiment commenced (approximately $6 \mathrm{mo}$ ) as part of a separate, wholelactation experiment. Immediately before the com- 
Table 2. Mean $( \pm \mathrm{SD})$ DIM, age, BW, daily ECM yield, and cumulative lactation yields of milk, protein, and fat for cows in the 6 groups of 36 immediately before the commencement of the experiment

\begin{tabular}{|c|c|c|c|c|c|c|c|c|}
\hline $\begin{array}{l}\text { Feeding } \\
\text { strategy }^{1}\end{array}$ & Replicate & DIM & Age (yr) & BW (kg) & $\operatorname{ECM}(\mathrm{kg} / \mathrm{d})$ & Milk (kg) & Protein (kg) & Fat (kg) \\
\hline \multirow[t]{2}{*}{ Control } & $\mathrm{A}$ & $226 \pm 17.7$ & $4.7 \pm 1.47$ & $593 \pm 61.8$ & $19.0 \pm 2.39$ & $5,338 \pm 699.0$ & $168 \pm 20.8$ & $239 \pm 39.1$ \\
\hline & $\mathrm{B}$ & $228 \pm 17.3$ & $4.3 \pm 1.53$ & $581 \pm 63.1$ & $18.8 \pm 3.09$ & $5.437 \pm 716.0$ & $169 \pm 22.0$ & $237 \pm 29.8$ \\
\hline PMR 1 & B & $228 \pm 17.1$ & $4.9 \pm 1.62$ & $605 \pm 56.7$ & $19.4 \pm 3.32$ & $5,538 \pm 893.1$ & $171 \pm 25.2$ & $237 \pm 35.9$ \\
\hline \multirow[t]{2}{*}{ PMR 2} & $\mathrm{~A}$ & $226 \pm 17.0$ & $4.5 \pm 1.61$ & $601 \pm 61.8$ & $19.9 \pm 2.84$ & $5,314 \pm 737.9$ & $169 \pm 22.9$ & $233 \pm 48.4$ \\
\hline & $\mathrm{B}$ & $229 \pm 18.6$ & $4.5 \pm 1.80$ & $608 \pm 63.1$ & $19.5 \pm 4.48$ & $5,536 \pm 970.8$ & $175 \pm 29.9$ & $240 \pm 40.8$ \\
\hline
\end{tabular}

${ }^{1}$ Control $=$ cows grazed perennial ryegrass pasture supplemented with milled barley grain fed in the milking parlor and pasture silage offered in the paddock; partial mixed ration (PMR) 1 = same pasture and allotment supplemented with the same amounts of milled barley grain and pasture silage, but presented as a mixed ration after each milking; PMR 2 = same pasture and allotment, supplemented with a mixed ration of milled barley grain, alfalfa hay, corn silage, and crushed corn grain.

mencement of the experiment, each group of 36 cows was further divided into 4 groups of 9 cows (a total of 24 groups; Table 1), again balanced for age, BW, DIM, and prevailing yield of milk, milk protein, and milk fat. Within each group of 36 cows, 1 group of 9 cows was randomly assigned to receive 1 of 4 amounts of supplement. These were approximately $6,8,10$, or $12 \mathrm{~kg}$ of total supplement DM/cow per day. Thus, there were 2 replicate groups of 9 cows per amount of supplement per feeding strategy. Each group of 9 cows contained a rumen-fistulated cow.

Cows fed using the PMR 1 and PMR 2 strategies received their supplements on the feed pad, with groups of 9 cows separated by electric tapes. Control cows were hand fed their barley grain in the milking parlor at each milking, whereas the pasture silage was fed to the control cows by placing the allocation for each group of 9 cows under an electric wire in their grazing area each day. Cows receiving the largest amount of supplement (12 $\mathrm{kg}$ of $\mathrm{DM} / \mathrm{cow}$ per day) were introduced gradually to dietary regimens, reaching their full amount of ration $5 \mathrm{~d}$ after the commencement of the preexperimental period. All cows had several opportunities each day to access water ad libitum from troughs located in and adjacent to the milking parlor, and in laneways adjacent to the paddocks used for grazing.

\section{Supplement Intake and Nutritive Characteristics}

Samples of the ration components (barley grain, corn grain, corn silage, alfalfa hay, and pasture silage) were collected on $3 \mathrm{~d} /$ wk during the measurement period and composited by week. Each sample was frozen, freeze dried, ground through a $0.5-\mathrm{mm}$ sieve and analyzed at a commercial laboratory (Dairy One Forage Laboratory, Ithaca, NY) for nutritive characteristics by near-infrared spectroscopy (AOAC International, 2000). Concentrations of estimated ME were predicted from DM digestibility (DMD\%) using the following formulas (Standing Committee on Agriculture, 1990; CSIRO 2007):

Pasture, hay, and grain $\mathrm{ME}(\mathrm{MJ} / \mathrm{kg}$ of $\mathrm{DM})=$

$$
(0.17 \times \mathrm{DMD} \%)-2.0
$$

Silage ME $(\mathrm{MJ} / \mathrm{kg}$ of $\mathrm{DM})=$

$$
(0.172 \times \mathrm{DMD} \%)-1.707 .
$$

Grain (control cows) and ration (PMR 1 and PMR 2 cows) offered and refused were weighed every day of the measurement period. Samples of grain and ration

\begin{tabular}{|c|c|c|c|c|c|c|c|c|c|}
\hline Item & $\mathrm{CP}$ & $\mathrm{ADF}$ & NDF & Lignin & $\mathrm{NFC}$ & Starch & $\mathrm{CF}^{2}$ & Ash & $\mathrm{ME}^{3}$ \\
\hline Crushed corn grain & 10.2 & 4.7 & 12.1 & 1.5 & 72.3 & 63.8 & 5.3 & 1.8 & 14.4 \\
\hline Pasture silage & 16.3 & 33.3 & 54.9 & 5.1 & 16.9 & 1.7 & 5.9 & 9.7 & 10.1 \\
\hline Alfalfa hay & 20.9 & 32.5 & 38.9 & 6.7 & 32.5 & 1.1 & 2.2 & 9.1 & 10.0 \\
\hline Pasture offered & 22.4 & 30.0 & 56.6 & 4.2 & 9.4 & 0.3 & 5.1 & 11.7 & 11.4 \\
\hline Pasture residual & 17.0 & 34.1 & 62.3 & 4.3 & 11.4 & 0.3 & 3.4 & 10.8 & 10.1 \\
\hline
\end{tabular}

Table 3. Mean nutritive characteristics of feed components and pasture ${ }^{1}$

${ }^{1}$ Data are means (\% of DM, unless otherwise indicated) for all samples collected during the 11-d measurement period.

${ }^{2}$ Crude fat.

${ }^{3}$ Estimated ME (MJ/kg of DM). 
refused were collected every day of the measurement period and a subsample analyzed for DM and nutritive characteristics, which allowed the calculation of daily intake of DM and estimated ME for each group of cows. No refusals of silage in the paddocks (control cows) were observed; therefore, it was assumed that all silage was consumed.

\section{Grazing}

Each day's pasture allowance was approximately 14 $\mathrm{kg}$ of DM/cow per day (to ground level) and was available as a single plot of 0.033 to 0.036 ha pasture per day. Cows did not return to the same plot during the course of the 25-d experiment. Control cows had access to pasture immediately after each milking. Cows fed according to the PMR 1 and PMR 2 strategies had access to pasture after they had consumed their ration on the feed pad following each milking. Cows grazed in groups of 9 on adjacent areas separated from the other groups by electric tapes. Cows were prevented from regrazing areas that had been grazed on previous days.

\section{Pasture Intake and Nutritive Characteristics}

Pre- and postgrazing pasture mass was estimated every day for each group of 9 cows using a C-Dax pasture meter (pasture meter XP1; C-Dax Ltd., Palmerston North, New Zealand). This information was used to calculate average pasture DMI for each group. The CDax pasture meter was calibrated for each new set of paddocks the cows entered.

For each new paddock, representative samples of pasture on offer were collected pregrazing for each of the six 36-cow groups in the experiment for assessment of pasture nutritive characteristics. Samples of pasture were collected postgrazing from each group of 9 cows (due to potential differences in residual pasture mass and nutritive characteristics). All pre- and postgrazing samples were collected by cutting pasture to ground level using electric shears at several points along a transect of the grazing area.

Pasture samples were thoroughly mixed, and then subsampled, washed, freeze dried, and ground through a $0.5-\mathrm{mm}$ sieve. Dried samples were analyzed for nutritive characteristics as described for supplement. Data from pre- and postgrazing pasture samples were combined with estimates of pre- and postgrazing mass to calculate the nutritive characteristics of pasture consumed.

\section{Ruminal Fluid VFA, Ammonia, and $\mathrm{pH}$}

Samples of ruminal fluid were collected from each of the rumen-fistulated cows at intervals of approximately
$2 \mathrm{~h}$ over two 24-h periods during the measurement period. This was done by restraining the cows in temporary yards set up in the paddock, or in permanent yards next to the feed pad and milking parlor. Samples were collected per fistulae using a $100-\mathrm{mL}$ plastic syringe connected to a brass pipe inserted into the rumen. Fluid was collected from several sites within the rumen.

For VFA analyses, an aliquot of $4 \mathrm{~mL}$ of ruminal fluid was dispensed into a tube containing $1 \mathrm{~mL}$ of $25 \%$ metaphosphoric acid before being stored at $-20^{\circ} \mathrm{C}$ until subsequent analysis. Concentrations of VFA were determined by capillary gas chromatography using the method of Packer et al. (2011). Sample VFA peaks were identified by comparing their retention time with those of a standard mixture of VFA (Sigma-Aldrich Pty Ltd., Castle Hill, NSW, Australia) and quantified using Shimadzu class GC10 version 1.62 software (Shimadzu Scientific Instruments, Rydalmere, NSW, Australia) using 4-methylvaleric acid as the internal standard. Results were calculated as parts per million and converted to millimoles per liter for subsequent analyses. The ratio of acetate plus butyrate to propionate $[(\mathbf{A}+\mathbf{B}) / \mathbf{P}]$ was calculated from molar concentrations.

For ammonia-N analysis, an aliquot of $10 \mathrm{~mL}$ of ruminal fluid was dispensed into a tube containing $10 \mathrm{~mL}$ of $0.1 \mathrm{M} \mathrm{HCl}$ before being stored at $-20^{\circ} \mathrm{C}$ until analysis. Concentrations of ammonia were assayed by a direct enzymatic procedure using a commercially available kit (Boehringer Mannheim; R-Biopharm Laboratory Diagnostics Pty Ltd., Taren Point, NSW, Australia) and a Cobas Mira S autoanalyzer (Roche, Montclair, NJ). Samples were analyzed immediately after collection for $\mathrm{pH}$ using a portable $\mathrm{pH}$ meter (Hanna HI9023 pH meter; Hanna Instruments, Keysborough, Victoria, Australia).

\section{Milk Yield and Composition}

Milk yield of every cow was measured at every milking during both the preexperimental and measurement periods using a DeLaval ALPRO milk metering system (DeLaval International AB, Tumba, Sweden). Fat and protein concentrations of the daily milk from each cow were determined on $2 \mathrm{~d} /$ wk during the measurement period. This was done by using inline milk meters (DeLaval International AB) to collect representative milk samples from consecutive afternoon and morning milkings, analyzing the p.m. and a.m. milk separately, and then calculating a weighted average in proportion to the yield at each milking. Milk samples were tested for concentrations of protein and fat using an infrared milk analyzer (model 2000; Bentley Instruments Inc., Chaska, MN). Energy-corrected milk, standardized to 
$4.0 \%$ fat and $3.3 \%$ protein, was calculated using the following formula (Tyrrell and Reid, 1965):

$$
\begin{gathered}
\text { ECM }(\mathrm{kg} / \text { cow per day })=\text { milk yield } \mathrm{kg} \\
\times(376 \times \text { fat } \%+209 \times \text { protein } \%+948) / 3,138 .
\end{gathered}
$$

\section{Statistical Analyses}

Statistical analyses were conducted on treatment period data means for each group of 9 cows. For ECM yield, milk yield, fat concentration and yield, and protein concentration and yield, these were derived by averaging over the treatment period within cows before averaging over cows within groups. The averages were analyzed using REML in GenStat for Windows software (GenStat release 14; VSN International Ltd., Hemel Hempstead, UK). The fixed effects in the REML model consisted of the factor treatment (control, PMR 1, or PMR 2) by (i.e., main effects and interaction with) a second-order orthogonal polynomial for DMI. The linear and quadratic orthogonal polynomial terms enable a clear distinction to be drawn between linear trend and curvature of responses to DMI. Fitted curves were reexpressed and reported as simple quadratic or linear functions of DMI. Marginal responses were estimated using derivatives of the fitted quadratic curves at specified DMI values and standard errors were derived from the coefficient variance-covariance matrix. Random effects in the REML model consisted of herd split for group, in keeping with the nested experimental design. The model used was as follows:

$$
\begin{aligned}
y_{i j}=\mu+\tau_{t}+ & \alpha \times D M I_{i j}+\beta \times D M I_{i j}^{2}+\gamma_{t} \times D M I_{i j} \\
& +\lambda_{t} \times D M I_{i j}^{2}+h_{j}+e_{i j}
\end{aligned}
$$

for group $i$ in herd $j$, where $y$ is the variable, $\mu=$ constant, $\tau_{t}=$ main effect of treatment $(t=$ control, PMR 1 , or PMR 2), $\alpha=$ slope of linear main effect for DMI, $\beta=$ quadratic main effect for DIM, $\gamma_{t}=$ interaction of treatment on linear effect of DMI, $\lambda_{t}=$ interaction of treatment on quadratic effect of DMI, $h_{j}=$ random effect of herd $j$, and $\mathrm{e}_{i j}=$ residual error for group $i$ in herd $j$. Greek letters indicate constants that describe the mean response, whereas Latin lowercase letters indicate independent random variables assumed to be normally distributed with variances to be estimated from the data.

Intake data (group averages) were analyzed by ANOVA, with factorial treatment structure, strategy by supplement amount, and nested blocking structure, herd split for group. Data for VFA were analyzed by
ANOVA with factorial treatment structure, strategy by supplement amount by interval, and nested blocking structure, herd split for cow split for interval.

Time was measured from the beginning of morning milking, and rumen $\mathrm{pH}$ data were linearly interpolated over intervals (on average, length $=2 \mathrm{~h}$ ) between measurement times for a 24 -h period. Using the interpolated data, the following were calculated for each fistulated cow: time under $\mathrm{pH} 6$, area under $\mathrm{pH} 6(\mathrm{pH} \times \mathrm{h})$, maximum $\mathrm{pH}$, minimum $\mathrm{pH}$, mean $\mathrm{pH}$, and minimum $\mathrm{pH}$ within the first $7 \mathrm{~h}$ ( $\mathrm{pH}$ nadir). These summary statistics were subjected to ANOVA, as per the intake data.

\section{RESULTS}

\section{Supplement Intakes, Total Intakes, and Substitution Rates}

The feed composition is presented in Table 3. Supplement DMI and estimated ME intake from supplement both increased $(P<0.01)$ as the amount of supplement offered increased. They were also affected by feeding strategy $(P<0.001)$, being lower for PMR 1 than control and PMR 2 (Table 4). Total DMI and apparent ME intakes also increased $(P<0.001)$ with increasing amounts of supplement offered. (It is noted that supplement intake for the control feeding strategy may be slightly overestimated due to possibility of wastage of silage in the paddock, even though such wastage was too small to measure). Total DMI was not affected by feeding strategy $(P=0.089)$, but total apparent ME intake was affected $(P=0.042)$, being higher for PMR 2 than control and PMR 1. A small amount of substitution of supplements for pasture was measured (Table 4). At the highest amounts of supplement offered, substitution was numerically less for PMR 2 cows than PMR 1 and control cows.

\section{Pasture Allowances, Utilization, and Intakes}

Pregrazing pasture mass and pasture allowance per cow did not differ between groups $(P>0.27$; Table 4). Postgrazing pasture mass increased as the amount of supplement offered increased $(P=0.008)$ but was not affected by the feeding strategy $(P=0.445)$. As a consequence, pasture DMI $(P=0.006)$ and intake of estimated ME from pasture $(P=0.041)$ decreased as the amount of supplement offered increased, as did pasture utilization (defined as the percentage of pasture on offer, measured to ground level, which was consumed; $P$ $=0.006)$. Feeding strategy did not affect pasture DMI $(P=0.55)$, estimated ME intake from pasture $(P=$ $0.16)$, or pasture utilization $(P=0.73)$. 
Table 4. Pregrazing and residual pasture mass (kg of DM/ha), pasture allowance (kg of DM/cow per day), daily DMI (kg of DM/cow per day), intake of ME (MJ/cow per day) from pasture and supplement, pasture utilization (PU; \%), and pasture substitution rate (SR; $\mathrm{kg}$ of pasture DM/kg of supplement DM) for cows offered supplements according to the control, partial mixed ration (PMR) 1, and PMR 2 feeding strategies, at nominal amounts of $6,8,10$, or $12 \mathrm{~kg}$ of DM/cow per day

\begin{tabular}{|c|c|c|c|c|c|c|c|c|c|c|c|c|c|c|}
\hline \multirow[b]{2}{*}{ Item } & \multirow{2}{*}{$\begin{array}{l}\text { Supplement } \\
\text { offered }\end{array}$} & \multicolumn{2}{|c|}{ Pasture mass } & \multirow{2}{*}{$\begin{array}{l}\text { Pasture } \\
\text { allowance }\end{array}$} & \multicolumn{2}{|c|}{ Pasture } & \multicolumn{2}{|c|}{ Supplement } & \multicolumn{4}{|c|}{ Total intake } & \multirow[b]{2}{*}{$\mathrm{PU}^{2}$} & \multirow[b]{2}{*}{$\mathrm{SR}^{3}$} \\
\hline & & Pregrazing & Postgrazing & & DMI & $\mathrm{ME}$ & DMI & $\mathrm{ME}$ & DMI & $\mathrm{ME}$ & NDF & $\mathrm{CP}$ & & \\
\hline \multicolumn{15}{|l|}{ Treatment $^{4}$} \\
\hline \multirow[t]{4}{*}{ Control } & 6 & 3,820 & 1,310 & 14.4 & 9.5 & 113 & 5.9 & 76 & 15.4 & 189 & 6.98 & 3.13 & 65.5 & - \\
\hline & 8 & 3,740 & 1,280 & 14.1 & 9.4 & 114 & 7.9 & 102 & 17.2 & 216 & 7.36 & 3.26 & 65.8 & 0.08 \\
\hline & 10 & 3,650 & 1,390 & 13.8 & 8.6 & 108 & 9.8 & 127 & 18.4 & 235 & 7.18 & 3.71 & 61.8 & 0.37 \\
\hline & 12 & 3,610 & 1,450 & 13.6 & 8.2 & 100 & 11.8 & 152 & 19.9 & 253 & 7.81 & 3.51 & 59.7 & 0.19 \\
\hline \multirow{4}{*}{ PMR 1} & 6 & 3,780 & 1,330 & 14.3 & 9.3 & 111 & 5.6 & 73 & 14.9 & 184 & 6.55 & 3.10 & 64.6 & - \\
\hline & 8 & 3,760 & 1,330 & 14.2 & 9.2 & 109 & 7.5 & 98 & 16.7 & 207 & 7.12 & 3.06 & 64.4 & 0.07 \\
\hline & 10 & 3,810 & 1,410 & 14.4 & 9.1 & 106 & 9.3 & 121 & 18.4 & 227 & 7.74 & 3.00 & 63.0 & 0.04 \\
\hline & 12 & 3,870 & 1,780 & 14.6 & 7.9 & 91 & 11.2 & 145 & 19.1 & 237 & 7.65 & 3.28 & 53.5 & 0.65 \\
\hline \multirow[t]{4}{*}{ PMR 2} & 6 & 3,930 & 1,420 & 14.8 & 9.5 & 118 & 6.4 & 79 & 15.8 & 197 & 6.59 & 3.40 & 63.9 & - \\
\hline & 8 & 3,930 & 1,430 & 14.8 & 9.4 & 113 & 8.2 & 102 & 17.6 & 214 & 7.38 & 3.59 & 63.5 & 0.04 \\
\hline & 10 & 3,910 & 1,540 & 14.8 & 8.9 & 114 & 10.2 & 127 & 19.2 & 241 & 7.47 & 3.88 & 60.4 & 0.23 \\
\hline & 12 & 3,970 & 1,500 & 15.0 & 9.3 & 115 & 12.3 & 153 & 21.6 & 268 & 8.30 & 4.11 & 62.1 & -0.19 \\
\hline$P$-value, strategy & & 0.27 & 0.44 & 0.27 & 0.55 & 0.16 & 0.002 & 0.009 & 0.089 & 0.042 & 0.82 & 0.11 & 0.73 & - \\
\hline$P$-value, amount & & 0.56 & 0.008 & 0.50 & 0.006 & 0.041 & $<0.001$ & $<0.001$ & $<0.001$ & $<0.001$ & $<0.001$ & 0.054 & 0.006 & - \\
\hline $\mathrm{LSD}^{5}$ & & 337 & 276 & 1.23 & 1.22 & 14.3 & 0.19 & 2.43 & 1.18 & 14.05 & 0.856 & 0.661 & 7.0 & - \\
\hline
\end{tabular}

${ }^{1}$ Data are means from the 11-d measurement period.

${ }^{2}$ Pasture utilization $=($ pasture consumed $/$ pasture allowance $) \times 100$

${ }^{3}$ Substitution rate $=$ reduction in pasture DMI/increase in supplement DMI.

${ }^{4}$ Control = cows grazed perennial ryegrass pasture supplemented with milled barley grain fed in the milking parlor and pasture silage offered in the paddock; PMR 1 = same pasture and allotment supplemented with the same amounts of milled barley grain and pasture silage, but presented as a mixed ration after each milking; PMR $2=$ same pasture and allotment, supplemented with a mixed ration of milled barley grain, alfalfa hay, corn silage, and crushed corn grain.

${ }^{5}$ Least significant difference $(P<0.05)$ for the comparison between treatments within amounts of supplement. 


\section{Ruminal Fluid VFA, Ammonia, and pH}

Concentrations of total VFA and ammonia, along with proportions of acetic, propionic, butyric, and valeric acids and the $(\mathrm{A}+\mathrm{B}) / \mathrm{P}$ ratio in ruminal fluid from cows on the 3 feeding strategies at the 4 amounts of supplement are presented in Table 5. Feeding strategy had no effect $(P>0.10)$ on any of these variables. The proportions of acetic acid decreased as amount of supplement offered increased $(P<0.001)$, whereas the proportions of propionic acid increased. The $(\mathrm{A}+\mathrm{B}) / \mathrm{P}$ ratio decreased $(P<0.001)$ with increasing amounts of supplement offered.

Features of the daily variation in ruminal $\mathrm{pH}$ for cows fed according to the 3 feeding strategies at the 4 amounts of supplement are presented in Table 6 . No differences $(P>0.10)$ were observed between feeding strategies for time under $\mathrm{pH} 6.0$, area under $\mathrm{pH} 6.0$, maximum $\mathrm{pH}$, minimum $\mathrm{pH}, \mathrm{pH}$ nadir after $7 \mathrm{~h}$, or mean daily $\mathrm{pH}$. An influence of amount of supplement on minimum $\mathrm{pH}$ and mean daily $\mathrm{pH}$ was observed, with both decreasing $(P<0.03)$ as amount of supplement offered increased.

\section{Milk Yield and Composition}

Mean yields of milk, ECM, fat, and protein, and mean concentrations of milk fat and protein for cows on the 3 feeding strategies at the 4 amounts of supplement are presented in Figure 1. Fitted curves are also presented for each parameter measured: the equations describing these fitted curves are presented in Table 7. All of the 3 feeding strategies had significant $(P<$ 0.05 ) quadratic components of the response curves for yields of milk, ECM, fat, and protein (with the exception of protein yield for PMR 1), but not for milk fat and protein concentrations. Consequently, the response curves of fat and protein concentrations to increasing supplement intake are presented as linear.

Cows on the PMR 2 feeding strategy had higher $(P$ $<0.01$ ) concentrations of fat at supplement intakes of between 9 and $11 \mathrm{~kg}$ of DM/cow per day than cows on the control or PMR 1 feeding strategies, and higher $(P<0.05)$ yields of fat at a supplement intake of 11 $\mathrm{kg}$ of $\mathrm{DM} /$ cow per day. No significant differences were observed in yields of milk, ECM, or protein, or in the concentrations of milk protein for cows on the 3 feeding strategies at any amount of supplement.

\section{Marginal ECM Responses to Supplement}

Marginal responses in ECM yield to increasing intakes of supplement are presented in Table 8. Responses were greater $(P<0.05)$ for cows offered PMR 2 than for the other 2 feeding strategies for total supplement intakes of between 9.0 and $10.0 \mathrm{~kg} /$ cow per day. At $11.0 \mathrm{~kg}$ of $\mathrm{DM} /$ cow per day, the ECM response for PMR 2 cows was greater $(P<0.05)$ than for control cows, but not PMR 1 cows.

For control cows, the total supplement intake at which ECM yield was maximized was $10.0 \mathrm{~kg}$ of DM/ cow per day. This was lower $(P<0.05)$ than the 11.7 $\mathrm{kg}$ of DM/cow per day predicted for PMR 2 cows, but not different to the $10.2 \mathrm{~kg}$ of $\mathrm{DM} / \mathrm{cow}$ per day for PMR 1 cows.

\section{DISCUSSION}

Milk production responses to offering increasing amounts of cereal-based concentrates in the milking parlor at milking times have been studied for many years and are well described (Doyle et al., 2001). The current study, however, is the first to measure the marginal milk production responses of grazing dairy cows to supplementary grain and forage provided as a PMR. Limited previous studies from countries other than Australia have shown that increasing proportions of PMR in the diets of pasture-fed dairy cows can increase milk production (Bargo et al., 2002; Vibart et al., 2008), but these experiments have not documented the marginal responses of increasing amounts of PMR offered to cows grazing a fixed pasture allowance.

As supplement intake increased, cows from all diet treatments exhibited quadratic ECM production responses, and at a supplement intake of $11.0 \mathrm{~kg}$ of DM/ cow per day, marginal ECM production responses had become negative for control and PMR 1 cows, and close to zero for PMR 2 cows. These observations support the first hypothesis that the control response would be quadratic, but not the second and third hypotheses that the ECM production response of PMR 1 and PMR 2 cows would be linear. Such diminishing marginal milk production responses to increasing amounts of supplement have been documented previously in grazing cows (Doyle et al., 2001) and are due to a range of factors including inefficiencies in rumen fermentation induced by low and fluctuating rumen $\mathrm{pH}$ as well as increased substitution of pasture for supplement.

The PMR 1 treatment was included in the experiment to determine whether the form in which the supplements were presented had an influence on the milk production response to increasing amounts of supplement. It was hypothesized that feeding the same amounts of cereal grain and pasture silage (and, thus, the same amount of estimated $\mathrm{ME}$ ) as the control cows were receiving as a PMR on a feed pad would improve milk production responses at the higher supplement intakes (by increasing the time taken to ingest the grain and thereby 

Table 5. Mean daily VFA concentrations in ruminal fluid of cows offered supplements according to the control, partial mixed ration (PMR) 1 , and PMR 2 feeding strategies at
nominal amounts of $6,8,10$, or $12 \mathrm{~kg}$ of DM/cow per day ${ }^{1}$

\begin{tabular}{|c|c|c|c|c|c|c|c|c|c|c|c|c|c|c|c|}
\hline \multirow[b]{3}{*}{ Item } & \multicolumn{12}{|c|}{ Feeding strategy $^{2}$} & & & \\
\hline & \multicolumn{4}{|c|}{ Control } & \multicolumn{4}{|c|}{ PMR 1} & \multicolumn{4}{|c|}{ PMR 2} & \multicolumn{2}{|c|}{$P$-value } & \multirow[b]{2}{*}{$\mathrm{LSD}^{3}$} \\
\hline & 6 & 8 & 10 & 12 & 6 & 8 & 10 & 12 & 6 & 8 & 10 & 12 & Strategy & Amount & \\
\hline Total VFA $(\mathrm{mmol} / \mathrm{L})$ & 118 & 129 & 134 & 126 & 116 & 130 & 127 & 123 & 106 & 130 & 127 & 134 & 0.95 & 0.063 & 31.5 \\
\hline Acetic acid (\%) & 65.7 & 65.2 & 65.8 & 63.4 & 65.7 & 65.6 & 64.2 & 54.2 & 66.8 & 65.7 & 65.0 & 61.9 & 0.38 & $<0.001$ & 5.22 \\
\hline Propionic acid (\%) & 17.3 & 17.5 & 18.5 & 19.9 & 17.6 & 17.5 & 18.1 & 31.5 & 16.6 & 18.4 & 18.8 & 21.8 & 0.41 & 0.001 & 0.28 \\
\hline Butyric acid (\%) & 13.9 & 14.0 & 12.3 & 13.3 & 13.1 & 13.3 & 13.7 & 9.6 & 12.9 & 12.5 & 12.7 & 12.5 & 0.29 & 0.17 & 0.16 \\
\hline Valeric acid (\%) & 1.0 & 1.1 & 1.0 & 1.1 & 1.1 & 1.1 & 1.1 & 2.2 & 1.0 & 1.0 & 1.1 & 1.3 & 0.45 & 0.092 & 0.45 \\
\hline$(\mathrm{A}+\mathrm{B}) / \mathrm{P}^{4}$ & 4.7 & 4.6 & 4.3 & 4.0 & 4.5 & 4.5 & 4.3 & 2.1 & 4.9 & 4.3 & 4.2 & 3.6 & 0.58 & $<0.001$ & 1.38 \\
\hline Ammonia (mg/L) & 142 & 127 & 138 & 109 & 129 & 183 & 151 & 83 & 130 & 164 & 111 & 137 & 0.97 & 0.074 & 44.9 \\
\hline
\end{tabular}

${ }^{1}$ Data are means of 2 cows per amount of supplement per diet.

${ }^{2}$ Control $=$ cows grazed perennial ryegrass pasture supplemented with milled barley grain fed in the milking parlor and pasture silage offered in the paddock; PMR $1=$ same pasture and allotment supplemented with the same amounts of milled barley grain and pasture silage, but presented as a mixed ration after each milking; PMR 2 = same pasture and allotment, supplemented with a mixed ration of milled barley grain, alfalfa hay, corn silage, and crushed corn grain.

${ }^{3}$ Least significant difference $(P<0.05)$ for the comparison between feeding strategies within amounts of supplement.

${ }^{4}$ The ratio of acetate $(\mathrm{A})$ plus butyrate $(\mathrm{B})$ to propionate $(\mathrm{P})$, given in molar proportions.

Table 6. Features of the daily variation in the $\mathrm{pH}$ of ruminal fluid for cows fed supplements according to the control, partial mixed ration (PMR) 1 , and PMR 2 feeding strategies at nominal amounts of $6,8,10$, or $12 \mathrm{~kg}$ of $\mathrm{DM} / \mathrm{cow}$ per day ${ }^{1}$

\begin{tabular}{|c|c|c|c|c|c|c|c|c|c|c|c|c|c|c|c|}
\hline \multirow[b]{3}{*}{ Item } & \multicolumn{12}{|c|}{ Feeding strategy ${ }^{2}$} & & & \\
\hline & \multicolumn{4}{|c|}{ Control } & \multicolumn{4}{|c|}{ PMR 1} & \multicolumn{4}{|c|}{ PMR 2} & \multicolumn{2}{|c|}{$P$-value } & \multirow[b]{2}{*}{$\mathrm{LSD}^{3}$} \\
\hline & 6 & 8 & 10 & 12 & 6 & 8 & 10 & 12 & 6 & 8 & 10 & 12 & Strategy & Amount & \\
\hline Time under $\mathrm{pH} 6.0^{4}(\mathrm{~d})$ & 0.366 & 0.405 & 0.502 & 0.521 & 0.295 & 0.418 & 0.477 & 0.469 & 0.125 & 0.274 & 0.316 & 0.285 & 0.42 & 0.066 & 0.4129 \\
\hline Area under $\mathrm{pH} 6.0^{5}(\mathrm{pH} \times \mathrm{h})$ & 2.12 & 2.18 & 2.89 & 3.20 & 2.05 & 2.46 & 3.24 & 4.24 & 0.60 & 1.20 & 1.68 & 2.02 & 0.52 & 0.057 & 3.853 \\
\hline Maximum pH & 7.00 & 6.87 & 6.93 & 7.02 & 7.27 & 7.12 & 6.94 & 7.16 & 6.99 & 7.11 & 7.03 & 6.94 & 0.61 & 0.44 & 0.464 \\
\hline Minimum $\mathrm{pH}$ & 5.62 & 5.64 & 5.51 & 5.38 & 5.65 & 5.65 & 5.46 & 5.17 & 5.77 & 5.71 & 5.50 & 5.51 & 0.45 & 0.006 & 0.334 \\
\hline $\mathrm{pH}$ nadir after $7 \mathrm{~h}^{6}$ & 5.77 & 5.85 & 5.71 & 5.77 & 5.94 & 5.97 & 5.78 & 5.50 & 6.34 & 5.96 & 5.99 & 5.93 & 0.31 & 0.058 & 0.496 \\
\hline Mean daily $\mathrm{pH}$ & 6.23 & 6.18 & 6.11 & 6.11 & 6.28 & 6.11 & 6.08 & 6.10 & 6.50 & 6.28 & 6.29 & 6.18 & 0.41 & 0.028 & 0.362 \\
\hline
\end{tabular}

${ }^{1}$ Data are means of 2 cows per amount of supplement per feeding strategy.

${ }^{2}$ Control $=$ cows grazed perennial ryegrass pasture supplemented with milled barley grain fed in the milking parlor and pasture silage offered in the paddock; PMR $1=$ same pasture and allotment supplemented with the same amounts of milled barley grain and pasture silage, but presented as a mixed ration after each milking; PMR 2 = same pasture and allotment, supplemented with a mixed ration of milled barley grain, alfalfa hay, corn silage, and crushed corn grain.

${ }^{3}$ Least significant difference $(P<0.05)$ for the comparison between feeding strategies within amounts of supplement.

${ }^{4}$ Mean time per day during which ruminal $\mathrm{pH}$ was below 6.0.

${ }^{5}$ Area of the $\mathrm{pH}$ versus time of day curve below $\mathrm{pH} 6.0(\mathrm{pH} \times \mathrm{h})$.

${ }^{6}$ Ruminal fluid $\mathrm{pH} 7 \mathrm{~h}$ after the morning milking. 

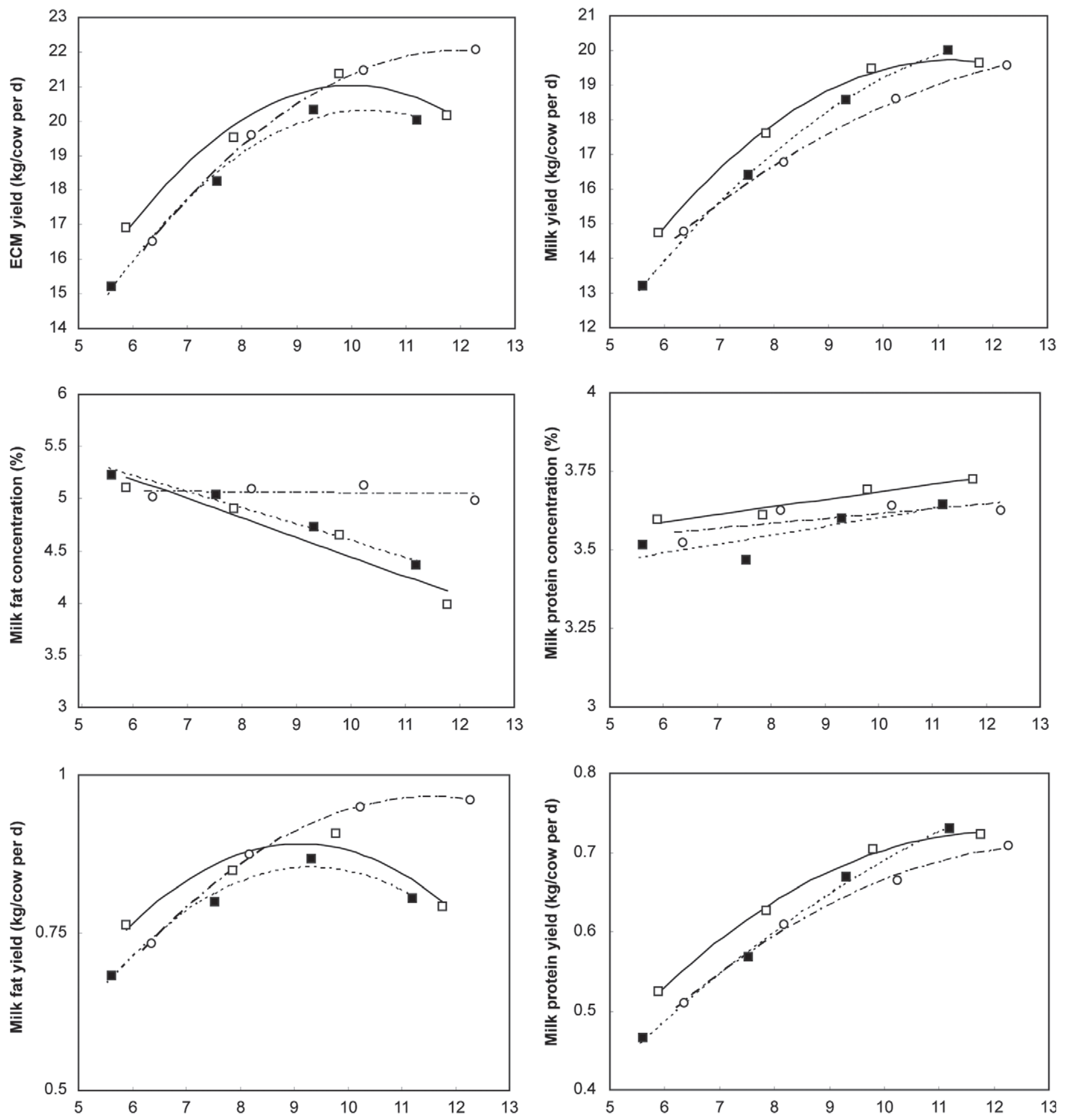

Supplement intake (kg of DM/cow per d)

Figure 1. Mean daily yields of milk and ECM, and concentrations and yields of milk protein and fat, for cows fed different amounts of supple-

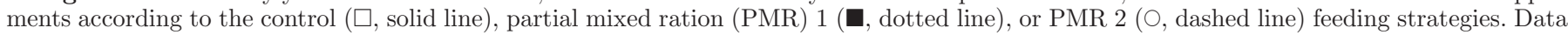
are means from the 11-d measurement period. Curves were fitted for the control (solid line), PMR 1 (dotted line), and PMR 2 (long dashed line) feeding strategies. Control = cows grazed perennial ryegrass pasture supplemented with milled barley grain fed in the milking parlor and pasture silage offered in the paddock; PMR 1 = same pasture and allotment supplemented with the same amounts of milled barley grain and pasture silage, but presented as a mixed ration after each milking; PMR $2=$ same pasture and allotment, supplemented with a mixed ration of milled barley grain, alfalfa hay, corn silage, and crushed corn grain. 
Table 7. Equations describing the relationships between supplement DMI (kg of total supplement DM/cow per day) and milk yield (MY), ECM yield, fat concentration (F\%), fat yield (FY), protein concentration (P\%), and protein yield (PY), for cows fed supplements according to the control, partial mixed ration (PMR) 1, and PMR 2 feeding strategies ${ }^{1}$

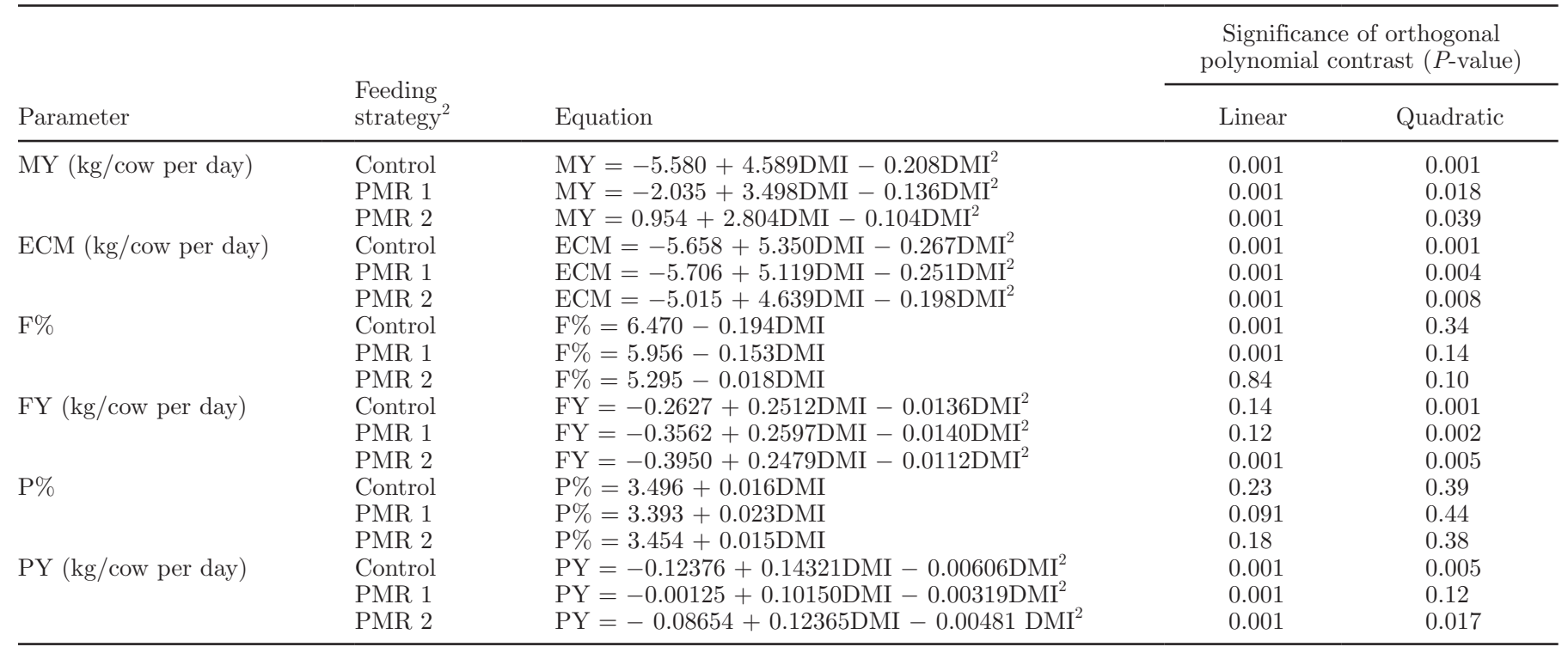

${ }^{1}$ These equations are derived from curves fitted to the mean measured values at 4 amounts of supplement per feeding strategy. Orthogonal polynomial contrasts test linear trend and quadratic curvature of the data independently.

${ }^{2}$ Control $=$ cows grazed perennial ryegrass pasture supplemented with milled barley grain fed in the milking parlor and pasture silage offered in the paddock; PMR 1 = same pasture and allotment supplemented with the same amounts of milled barley grain and pasture silage, but presented as a mixed ration after each milking; PMR 2 = same pasture and allotment, supplemented with a mixed ration of milled barley grain, alfalfa hay, corn silage, and crushed corn grain.

mitigating the severity of the variations and decline in rumen $\mathrm{pH}$ ). This was not observed, and thus the second part of the second hypothesis is also rejected. The ECM production response of cows offered PMR 1 was not different compared with that of the control cows at any level of supplement intake, and the 2 groups had a similar nonlinear ECM response to increasing amounts of supplement. The above observation indicates that under the low pasture allowance conditions of this experiment, presenting supplementary feeds in a simple mix such as PMR 1 has no milk production advantage over the traditional system of slug feeding grain in the milking parlor and presenting forage in the dock.

For PMR 2 cows, marginal ECM production responses to extra supplement were higher than for cows fed both the other diets at supplement intakes of 9.0 to $10.0 \mathrm{~kg}$ of $\mathrm{DM} / \mathrm{cow}$ per day, and greater than control cows at $11.0 \mathrm{~kg}$ of $\mathrm{DM} / \mathrm{cow}$ per day. This observation thus supports the second part of the third hypothesis. At $11.0 \mathrm{~kg}$ of supplement DM/cow per day, this difference in the marginal ECM response was of the order of $0.8 \mathrm{~kg}$ of $\mathrm{ECM} / \mathrm{cow}$ per day. It was also observed that the supplement DMI at which ECM production was maximized (i.e., the point at which marginal response was zero) was greater for PMR 2 cows $(11.7 \mathrm{~kg}$ of DM/ cow per day) than control cows $(10.2 \mathrm{~kg}$ of $\mathrm{DM} / \mathrm{cow}$ per day).
The increased fat yield and improved marginal ECM production responses of PMR 2 cows compared with cows on the other 2 diets at the highest level of supplementation were due, in large part, to milk fat concentration not declining with increasing supplement intake as it did for the control and PMR 1 cows. A

Table 8. Marginal responses ( $\mathrm{kg}$ of ECM/additional $\mathrm{kg}$ of supplement $\mathrm{DM}$ ) of cows offered increasing amounts of supplements offered according to the control, partial mixed ration (PMR) 1, and PMR 2 feeding strategies ${ }^{1}$

\begin{tabular}{lccc}
\hline & \multicolumn{3}{c}{ Feeding strategy $^{2}$} \\
\cline { 2 - 4 } Supplement & Control (SE) & PMR 1 (SE) & PMR 2 (SE) \\
\cline { 2 - 4 } & $1.6(0.26)$ & $1.6(0.23)$ & $1.9(0.31)$ \\
8.0 & $1.1(0.15)$ & $1.1(0.13)$ & $1.5(0.20)$ \\
9.0 & $0.6(0.11)^{\mathrm{a}}$ & $0.6(0.14)^{\mathrm{a}}$ & $1.1(0.12)^{\mathrm{b}}$ \\
10.0 & $0.0(0.19)^{\mathrm{a}}$ & $0.1(0.25)^{\mathrm{a}}$ & $0.7(0.14)^{\mathrm{b}}$ \\
11.0 & $-0.5(0.30)^{\mathrm{a}}$ & $-0.4(0.38)^{\mathrm{ab}}$ & $0.3(0.24)^{\mathrm{b}}$ \\
\hline
\end{tabular}

$\overline{\mathrm{a}, \mathrm{b}}$ Within rows, means with different superscripts are significantly different $(P<0.05)$.

${ }^{1}$ Data presented are calculated from the slopes of fitted quadratic curves at specified supplement DMI.

${ }^{2}$ Control $=$ cows grazed perennial ryegrass pasture supplemented with milled barley grain fed in the milking parlor and pasture silage offered in the paddock; PMR 1 = same pasture and allotment supplemented with the same amounts of milled barley grain and pasture silage, but presented as a mixed ration after each milking; PMR 2 = same pasture and allotment, supplemented with a mixed ration of milled barley grain, alfalfa hay, corn silage, and crushed corn grain. 
numerical but nonsignificant increase also was observed in ECM yield (predicted ECM yields at $11 \mathrm{~kg}$ of supplement $\mathrm{DM} /$ cow per day for control and PMR 2 cows were 20.8 vs. $22.0 \mathrm{~kg}$ of $\mathrm{ECM} /$ cow per day, $P=0.12$ ). The mechanisms involved in such reductions in milk fat concentration cows are not fully understood; however, diet is a major factor (Bauman and Griinari, 2003; Shingfield et al., 2010). Diets with low fiber and high starch and lipids rich in PUFA are often associated with milk fat depression (Stockdale et al., 1987). These types of diets are coincident with low ruminal fluid $\mathrm{pH}$ that cause a shift in the microbial population in the rumen and altered rumen lipid metabolism, leading to an increase in the amount of specific biohydrogenation intermediaries that have antilipogenic effects (Bauman and Griinari, 2003). The total diet consumed by control cows at a supplement rate of approximately $6 \mathrm{~kg}$ of DM had a starch concentration of $22 \% \mathrm{DM}$ and cows consuming this diet produced milk with a fat concentration of $5.2 \%$. When cows consumed $12 \mathrm{~kg}$ of DM of the control diet, however, the total diet starch concentration approximated $45 \% \mathrm{DM}$ and cows produced milk with a fat concentration of $4.3 \%$. In contrast, the PMR 2 cows consuming $12 \mathrm{~kg}$ of DM supplement were able to maintain their milk fat concentration despite the high starch in the total diet (43\%), which can be partly explained by the source of starch (Sutton, 1984). Approximately half of the starch from barley was replaced with corn grain starch, leading to potential differences in site and end products of digestion (Khorasani et al., 2001; Granzin, 2004).

Increased passage of starch to the duodenum and subsequent digestion would increase the availability of glucose for synthesis of lactose (and, therefore, milk yield) when corn replaced barley in the diet. In some studies, this increase in glucose availability has also been associated with an increase in milk protein concentration (Granzin, 2004), presumably via the sparing of amino acids from gluconeogenesis in the liver. This is not always observed, however (Khorasani et al., 2001), and in the present experiment, no difference in protein concentration was observed between feeding strategies. This is possibly related at least in part to milk protein concentrations already being high in all groups.

The increased marginal ECM response in PMR 2 cows compared with control cows can partially be attributed to a $13 \%$ higher pasture intake. Although pasture allowances were low and were set to minimize differences in pasture intake between the different groups, when cows were fed according to the control and PMR 1 strategies, pasture intakes decreased and residual pasture masses increased as the amount of supplement increased. Such substitution of supplement for pasture is common in grazing cows offered large amounts of supplement (Dixon and Stockdale, 1999; Wales et al., 1999; Walker et al., 2001). This was not observed, however, for cows consuming PMR 2. These cows substituted less at the highest supplement intake and maintained the same pasture DMI as PMR 2 cows offered lower amounts of supplement. As a consequence, cows offered $12 \mathrm{~kg}$ of DM/cow per day of PMR 2 ingested an estimated $15 \mathrm{MJ} /$ cow per day more ME from pasture than control cows offered the same amount of supplement, thus explaining approximately $60 \%$ of the additional ECM yield.

The reduced pasture intake of cows offered the large amounts of the control diet compared with PMR 2 may be partly explained by the differences in starch type. Several experiments have shown decreased intake by lactating cows on barley- versus corn-based TMR (Casper and Schingoethe, 1989; Casper et al., 1999; McCarthy et al., 1989; Bengochea et al., 2005). The explanation for the decrease relate to reductions in fiber digestibility, but also to the fact that PMR 2 cows were likely to have an increased passage of starch to the duodenum, increased digestibility of the starch, and potentially increased efficiency of use of the subsequent energy (Khorasani et al., 2001; Granzin, 2004).

It is generally accepted that NDF digestion is impaired when ruminal fluid $\mathrm{pH}$ falls below 6.0 (Mould et al., 1983). In the current experiment, cows on all treatments showed marked variation in ruminal fluid $\mathrm{pH}$ during the day. In agreement with the literature (Walker et al., 2001; Wales and Doyle, 2003; Leddin et al., 2010), the magnitude of this variation increased for all treatments with increasing amount of supplement offered: cows fed more had lower mean and minimum rumen $\mathrm{pH}$ than cows fed less. There were also trends for the ruminal fluid of cows consuming more supplement to be below 6.0 for longer than cows on the lower rates. Thus, it may be expected that ruminal NDF digestion was impaired when larger amounts of supplement were offered and that these cows were extracting a lower proportion of dietary ME than cows on the smaller amounts (Dixon and Stockdale, 1999).

Although the ruminal $\mathrm{pH}$ of PMR 2 cows was numerically higher and spent less time below 6.0 than for control and PMR 1 cows, the differences were not significant. It was speculated that the corn grain and corn silage in PMR 2 provided a source of starch that digested more slowly than the barley-based rations offered to the control and PMR 1 cows (Sutton, 1984). Because low rumen $\mathrm{pH}$ and ruminal acidosis occur due to ingestion of large quantities of readily digestible carbohydrates (e.g., barley grain), with a subsequent buildup of fermentation byproducts such as VFA and lactic acid (Bramley et al., 2008), it was expected that the inclusion of corn in PMR 2 would lead to a reduced 
extent of fluctuations of $\mathrm{pH}$ in the rumen due to a greater degree of postruminal digestion. Further experiments are needed to assess the whole-tract digestibility of these diets to understand why this was not observed.

No differences were observed in the daily patterns of ruminal fluid $\mathrm{pH}$ between the control and PMR 1 cows, which is consistent with the lack of difference between the milk production of these groups. One reason for this could be that the time during which cows ingested their supplements may not have been extended enough. Whereas the control cows consumed half their daily barley ration (which represented $37.5 \%$ of their daily supplement DMI) in around $15 \mathrm{~min}$, the cows offered PMR 1 took only around $1 \mathrm{~h}$ to consume $50 \%$ of their daily supplement DMI. This difference in the rate of supplement ingestion was presumably not large enough to mitigate the accumulation of the products of digestion in the rumen with the associated decline in ruminal fluid $\mathrm{pH}$.

The concentrations of VFA measured in ruminal fluid were affected by rate of feeding but not by diet type. This is in agreement with the rumen $\mathrm{pH}$ data, but contrasts with the results of Khorasani et al. (2001) that showed an increase in butyrate and decrease in acetate concentrations in ruminal fluid when barley was replaced with corn in a TMR. In the current experiment, as the intake of supplement increased and the ratio of dietary forage:concentrate decreased, proportions of ruminal acetate and butyrate decreased while propionate increased, for all diets. Given the lipogenic roles of acetate and butyrate and glucogenic role of propionate (Sutton, 1984), previous studies have shown that milk fat reduction is commonly associated with a decline in the ruminal $(\mathrm{A}+\mathrm{B}) / \mathrm{P}$ ratio, as was observed for control and PMR 1 cows. However, a decline in ruminal $(\mathrm{A}+\mathrm{B}) / \mathrm{P}$ ratios was also observed in PMR 2 cows as concentrate intake increased, but milk fat concentration was maintained. Again, further experiments are required to further elucidate the mechanisms by which the PMR 2 diet is able to arrest the decline in milk fat concentrations observed in cows fed the other 2 diets.

\section{CONCLUSIONS}

This experiment showed that when large amounts of supplements were fed to dairy cows grazing a restricted pasture allowance in late lactation, no production advantage was observed in offering a simple PMR of pasture silage and barley grain compared with feeding the same amount of energy according to traditional strategies of slug feeding grain in the milking parlor, with forage presented separately in the paddock. However, ECM production responses were greater when the supplements were fed as an isoenergetic PMR that also contained alfalfa hay, corn silage, and corn grain. Much of this increased response was due to the maintenance of milk fat concentrations at all levels of feeding for mixed rations containing corn grain and corn silage, compared with the marked decline in milk fat concentrations observed in the other 2 diets when supplement intake increased. Ruminal $\mathrm{pH}$ and concentrations of VFA were altered by increasing amounts of supplement but not by supplement type. These results have important implications for those sections of the dairy industry needing to feed large amounts of supplement when pasture is limited due to climatic conditions.

\section{ACKNOWLEDGMENTS}

The authors are grateful to G. Morris, A. McDonald, D. Clarkson, M. Norman, N. Gleeson (all of DPI), and DPI (Ellinbank, Victoria, Australia) farm staff for cow feeding and husbandry. Thanks to Dairy Australia's Nutrition Advisory Group (Southbank, Victoria, Australia) for support with the design and interpretation of this experiment, and John McNamara (Washington State University, Pullman) for help in the preparation of this manuscript. This research was funded by DPI and Dairy Australia (Melbourne, Australia).

\section{REFERENCES}

AOAC International. 2000. Official Methods of Analysis of AOAC International. 17th ed. AOAC Int., Gaithersburg, MD.

Armstrong, D. P., K. A. Tarrant, C. K. M. Ho, L. R. Malcolm, and W. J. Wales. 2010. Evaluating development options for a rain-fed dairy farm in Gippsland. Anim. Prod. Sci. 50:363-370.

Baird, D. B. 1994. The design of experiments with covariates. PhD Thesis. University of Otago, North Dunedin, New Zealand.

Bargo, F., L. D. Muller, E. S. Kolver, and J. E. Delahoy. 2003. Invited review: Production and digestion of supplemented dairy cows on pasture. J. Dairy Sci. 86:1-42.

Bargo, F., L. D. Muller, G. A. Varga, J. E. Delahoy, and T. W. Cassidy. 2002. Ruminal digestion and fermentation of high-producing dairy cows with three different feeding systems combining pasture and total mixed rations. J. Dairy Sci. 85:2964-2973.

Bauman, D. E., and J. M. Griinari. 2003. Nutritional regulation of milk fat synthesis. Annu. Rev. Nutr. 23:203-227.

Beever, D. E., and P. T. Doyle. 2007. Feed conversion efficiency as a key determinant of dairy herd performance: A review. Aust. J. Exp. Agric. 47:645-657.

Bengochea, W. L., G. P. Lardy, M. L. Bauer, and S. A. Soto-Navarro. 2005. Effect of grain processing degree on intake, digestion, ruminal fermentation, and performance characteristics of steers fed medium-concentrate growing diets. J. Anim. Sci. 83:2815-2825.

Bramley, E., I. J. Lean, W. J. Fulkerson, M. A. Stevenson, A. R. Rabiee, and N. D. Costa. 2008. The definition of acidosis in dairy herds predominantly fed on pasture and concentrates. J. Dairy Sci. 91:308-321.

Casper, D. P., H. A. Maiga, M. J. Brouk, and D. J. Schingoethe. 1999. Synchronization of carbohydrate and protein sources on fermentation and passage rates in dairy cows. J. Dairy Sci. 82:1779-1790.

Casper, D. P., and D. J. Schingoethe. 1989. Lactational response of dairy cows to diets varying in ruminal solubilities of carbohydrate and crude protein. J. Dairy Sci. 72:928-941. 
CSIRO. 2007. Nutrient Requirements of Domesticated Ruminants. M. Freer, H. Dove, and J.V. Nolan, ed. CSIRO Publ., Melbourne, Australia.

Dixon, R. M., and C. R. Stockdale. 1999. Associative effects between forages and grains: Consequences for feed utilisation. Aust. J. Agric. Res. 50:757-774.

Doyle, P. T., S. A. Francis, and C. R. Stockdale. 2005. Associative effects between feeds when concentrate supplements are fed to grazing dairy cows: A review of likely impacts on metabolisable energy supply. Aust. J. Agric. Res. 56:1315-1329.

Doyle, P. T. C. R. Stockdale, W. J. Wales, G. P. Walker, and J. W. Heard. 2001. Limits to and optimising of milk production and composition from pastures. Recent Adv. Anim. Nutr. Aust. 13:9-18.

Granzin, B. C. 2004. Effects of supplement grain type and level of feeding on the milk production of early-lactation Holstein-Friesian cows grazing temperate and tropical pastures. Aust. J. Exp. Agric. $44: 735-743$

Kellaway, R., and T. Harrington. 2004. Feeding Concentrates: Supplements for Dairy Cows. Rev. ed. Landlinks Press, Collingwood, Victoria, Australia.

Khorasani, G. R., E. K. Okine, and J. J. Kennelly. 2001. Effects of substituting barley grain with corn on ruminal fermentation characteristics, milk yield, and milk composition of Holstein cows. J. Dairy Sci. 84:2760-2769.

Kolver, E. S., and L. D. Muller. 1998. Performance and nutrient intake of high producing Holstein cows consuming pasture or a total mixed ration. J. Dairy Sci. 81:1403-1411.

Leddin, C. M., C. R. Stockdale, J. Hill, J. W. Heard, and P. T. Doyle. 2009. Increasing amounts of crushed wheat fed with pasture hay reduced dietary fiber digestibility in lactating dairy cows. J. Dairy Sci. 92:2747-2757.

Leddin, C. M., C. R. Stockdale, J. Hill, J. W. Heard, and P. T. Doyle. 2010. Increasing amounts of crushed wheat fed with Persian clover herbage reduced ruminal $\mathrm{pH}$ and dietary fibre digestibility in lactating dairy cows. Anim. Prod. Sci. 50:837-846.

McCarthy, R. D., Jr., T. H. Klusmeyer, J. L. Vicini, and J. H. Clark. 1989. Effects of source of protein and carbohydrate on ruminal fermentation and passage of nutrients to the small intestine of lactating cows. J. Dairy Sci. 72:2002-2016.

Mould, F. L., E. R. Ørskov, and S. O. Mann. 1983. Associative effects of mixed feeds. I. Effects of type and level of supplementation and the influence of the rumen fluid $\mathrm{pH}$ on cellulolysis in vivo and dry matter digestion of various roughages. Anim. Feed Sci. Technol. $10: 15-30$.

National Health and Medical Research Council. 2004. Australian Code of Practice for the Care and Use of Animals for Scientific Purposes. 7th ed. Australian Government, Canberra, Australia.
Packer, E. L., E. H. Clayton, and P. M. V. Cusack. 2011. Rumen fermentation and liveweight gain in beef cattle treated with monensin and grazing lush forage. Aust. Vet. J. 89:338-345.

Shingfield, K. J., L. Bernard, C. Leroux, and Y. Chilliard. 2010. Role of trans fatty acids in the nutritional regulation of mammary lipogenesis in ruminants. Animal 4:1140-1166.

Standing Committee on Agriculture. 1990. Feeding Standards for Australian Livestock. Ruminants. CSIRO Publ., Melbourne, Australia.

Stockdale, C. R., A. Callaghan, and T. E. Trigg. 1987. Feeding high energy supplements to pasture-fed dairy cows, effects of stage of lactation and level of supplement. Aust. J. Agric. Res. 38:927940

Sutton, J. D. 1984. Feeding and milk fat production. Pages $43-52$ in Milk Compositional Quality and Its Importance in Future Markets. Occasional Publ. 9. Br. Soc. Anim. Prod., Penicuik, UK.

Tedeschi, L. O., W. Chalupa, E. Janczewski, D. G. Fox, C. Sniffen, R. Munson, P. J. Kononoff, and R. Boston. 2008. Evaluation and application of the CPM dairy nutrition model. J. Agric. Sci. 146:171-182.

Tyrrell, H. F., and J. T. Reid. 1965. Prediction of energy value of cow's milk. J. Dairy Sci. 48:1215-1223.

Vibart, R. E., V. Fellner, J. C. Burns, G. B. Huntington, and J. T. Green. 2008. Performance of lactating dairy cows fed varying levels of total mixed ration and pasture. J. Dairy Res. 75:471-480.

Wales, W. J., D. W. Dellow, P. T. Doyle, and A. R. Egan. 2000. Effects of feeding additional pasture hay in autumn to dairy cows grazing irrigated perennial ryegrass-white clover pasture and supplemented with barley grain. Aust. J. Exp. Agric. 40:1-9.

Wales, W. J., and P. T. Doyle. 2003. Effect of grain and straw supplementation on marginal milk production responses and rumen function of cows grazing highly digestible subterranean clover pasture. Aust. J. Exp. Agric. 43:467-474.

Wales, W. J., P. T. Doyle, C. R. Stockdale, and D. W. Dellow. 1999. Effects of variations in herbage mass, allowance and level of supplement on nutrient intake and milk production of dairy cows in spring and summer. Aust. J. Exp. Agric. 39:119-130.

Wales, W. J., J. W. Heard, C. K. M. Ho, C. M. Leddin, C. R. Stockdale, G. P. Walker, and P. T. Doyle. 2006. Profitable feeding of dairy cows on irrigated dairy farms in northern Victoria. Aust. J. Exp. Agric. 46:743-752.

Walker, G. P., C. R. Stockdale, W. J. Wales, P. T. Doyle, and D. W. Dellow. 2001. Effect of level of grain supplementation on milk production responses of dairy cows in mid-late lactation when grazing irrigated pastures high in paspalum (Paspalum dilatatum Poir.). Aust. J. Exp. Agric. 41:1-11 